\title{
Peningkatan Prestasi Belajar Matematika Melalui Penerapan Lesson Plan Berbasis Multiple Intelligence
}

\author{
Vigih Hery Kristanto \\ Universitas Katolik Widya Mandala Madiun:vigihhery@staff.widyamandala.ac.id
}

\begin{abstract}
The purpose of this research is to find out in writing whether the mathematics achievement of students can be improved by the implementation of lesson plan based on Multiple Intelligence. This type of research is the study of literature with five steps, namely (1) collecting the literature and then do a review of some important terms in the study, (2) collecting relevant literature research result, (3) conducting in-depth analysis based on all the literature that has been obtained by the prepared discussion, (4) develop conclusions based on the analysis, (5) making recommendation based on the findings obtained. The conclusion of this research is that a written application of the lesson plan based on Multiple Intelligence has a tendency to increase student's mathematics achievement.

Keywords: learning achievement; lesson plan; multiple intelligence
\end{abstract}

\begin{abstract}
Abstrak
Tujuan dalam penelitian ini adalah untuk mengetahui secara tertulis, apakah prestasi belajar matematika siswa dapat meningkat melalui penerapan lesson plan berbasis Multiple Intelligence. Jenis penelitian ini adalah studi literatur, dengan lima tahapan, yaitu (1) mengumpulkan literatur kemudian melakukan review terhadap beberapa istilah penting dalam penelitian, (2) mengumpulkan literatur hasil penelitian relevan, (3) melakukan analisis secara mendalam berdasarkan semua literatur yang telah diperoleh dengan menyusun pembahasan, (4) menyusun kesimpulan berdasarkan hasil analisis, (5) mengajukan saran berdasarkan temuan-temuan yang diperoleh. Kesimpulan dari penelitian ini adalah secara tertulis penerapan lesson plan berbasis Multiple Intelligence memiliki kecenderungan untuk dapat meningkatkan prestasi belajar matematika siswa.
\end{abstract}

Kata Kunci: prestasi belajar; lesson plan; multiple intelligence.

\section{PENDAHULUAN}

Pembangunan suatu negara sangat dipengaruhi oleh pendidikan, sebab dengan bantuan pendidikan setiap individu dapat melaju dan berkembang, sehingga dikemudian hari mendapatkan pekerjaan yang pantas (Ratnasari, 2013). Proses pendidikan merupakan suatu sistem yang terdiri dari input, proses dan output. Input merupakan peserta didik yang akan melaksanakan aktivitas belajar, proses merupakan kegiatan dari belajar mengajar sedangkan output merupakan hasil dari proses yang dilaksanakan. Dari pelaksanaan proses pendidikan tersebut diharapkan dapat menghasilkan sumber daya manusia yang berkualitas dan berdaya saing yang tinggi untuk menghadapi persaingan di era globalisasi dewasa ini (Maja, 2013).

Belajar menjadi aktivitas umum manusia. Belajar tidak dapat dipisahkan dalam kehidupan keseharian manusia, karena dengan belajar manusia dapat memperoleh pengetahuan. Pengetahuan ini nantinya digunakan untuk menyelesaikan masalah dalam kehidupan sehari-hari. Dengan memiliki pengetahuan yang cukup, manusia dapat 
mempermudah kehidupannya. Oleh sebab itu, manusia diwajibkan untuk bersekolah, karena dengan bersekolah aktivitas belajar menjadi lebih sistematis. Sekolah yang dimaksud dalam pembahasan ini adalah sekolah formal. Dalam sekolah formal terdapat kurikulum yang mengatur proses pembelajaran.

Proses pembelajaran merupakan salah satu faktor yang sangat penting. Hasil pembelajaran dipengaruhi oleh proses belajar yang diciptakan guru. Guru yang mampu memfasilitasi siswa serta mampu memberikan proses pembelajaran yang menarik secara tidak langsung akan memberikan stimulus atau rangsangan kepada siswa untuk lebih aktif memperhatikan pembelajaran (Saputra, Sriyono, \& Ngazizah, 2013). Proses pembelajaran dapat membuat siswa sebagai subyek belajar yang melakukan aktivitas belajar. Aktivitas belajar yang dimaksud merupakan proses dimana siswa secara aktif mengkonstruksi sendiri pengetahuannya. Proses pengkonstruksian pengetahuan ini sesuai dengan belajar menurut paradigma konstruktivisme.

Konstruktivisme beranggapan bahwa pengetahuan manusia itu merupakan konstruksi (bentukan) dari manusia itu sendiri yang mengetahui sesuatu melalui interaksi mereka (siswa) dengan obyek, fenomena, pengalaman dan lingkungan mereka (siswa). Menurut Piaget mengatakan setiap siswa harus membangun sendiri pengetahuan-pengetahuan itu dan dikonstruksi sendiri (Supardi, Sunarno, \& Haryono, 2014). Dalam penelitian ini hasil dari pengetahuan baru disebut dengan istilah hasil belajar. Dengan demikian, hasil belajar tidak hanya sekedar perubahan perilaku (afektif), namun perubahan pada semua ranah yang meliputi kognitif, afektif, maupun psikomotorik. Hal ini sejalan dengan pendapat (Kusnandar, 2013), bahwa hasil belajar adalah kompetensi atau kemampuan tertentu baik kognitif, afektif, maupun psikomotorik yang dicapai atau dikuasai siswa setelah mengikuti proses pembelajaran.

Hasil belajar biasa disebut dalam istilah lain sebagai prestasi belajar. Prestasi belajar merupakan hal yang penting karena dapat menjadi petunjuk untuk mengetahui sejauh mana keberhasilan siswa dalam kegiatan belajar matematika yang sudah dilakukan (Pamungkas, Nugraheni, \& Astuti, 2013). Dalam penelitian ini, prestasi belajar hanya dilihat dalam satu ranah, yaitu ranah kognitif. Pengambilan satu ranah ini dimaksudkan agar penelitian menjadi lebih terfokus pada pembahasan tentang peningkatan ranah tersebut setelah siswa mengikuti proses pembelajaran. Berdasarkan semua uraian tersebut, dapat disimpulkan bahwa pengertian prestasi belajar yang digunakan dalam penelitian ini adalah hasil belajar ranah kognitif yang diperoleh siswa setelah mengikuti proses pembelajaran.

Dalam proses pembelajaran terdapat dua macam tipe pendekatan, yaitu top-down dan bottom-up. Dalam mata pelajaran matematika, contoh dari penggunaan pendekatan top-down untuk memahami konsep pembagian bilangan, sebagai berikut, (a) untuk mempelajari pembagian bilangan, disajikan permasalahan faktual yang sering dialami oleh siswa, seperti "harga sebuah permen Rp. 75,00. Jika Vigih membayar dengan uang sebesar Rp. 600,00, berapa permenkah yang dapat diperoleh Vigih?, (b) guru bertugas sebagai fasilitator, memberikan scaffolding kepada siswa, agar mereka dapat menemukan tahap-tahap penyelesaian dengan pemikiran mereka sendiri, sehingga siswa dengan sendirinya akan 
mempelajari konsep pembagian bilangan, (c) setelah siswa memahami konsep pembagian bilangan, maka akan muncul kesimpulan bahwa penyelesaian masalah tersebut adalah 600 : 75 , yang hasilnya sama dengan 8 permen.

Hasil yang diperoleh siswa setelah mengikuti proses pembelajaran dalam contoh di atas adalah penguasaan konsep pembagian bilangan. Penguasaan konsep merupakan salah satu aspek dalam ranah kognitif. Selain itu, konsep pembagian bilangan merupakan salah satu konsep dalam mata pelajaran matematika. Jika dikaitkan dengan prestasi belajar pada pembahasan sebelumnya, hasil belajar siswa yang berupa penguasaan konsep pembagian bilangan dapat disebut sebagai prestasi belajar matematika. Dengan demikian, prestasi belajar matematika dalam penelitian ini adalah hasil belajar ranah kognitif yang diperoleh siswa setelah mengikuti proses pembelajaran matematika. Implementasi dari contoh di atas sangat sulit untuk dilakukan mengingat siswa memiliki kemampuan (potensi) awal yang heterogen. Potensi yang heterogen ini merupakan bahan dasar yang menentukan kecepatan masingmasing siswa dalam memahami pembagian bilangan. Namun, kesulitan yang dialami dalam implementasi pendekatan top-down dapat diatasi dengan pembuatan rencana pembelajaran (lesson plan). Sehingga lesson plan yang disusun seyogyanya melibatkan potensi awal yang dimiliki oleh siswa.

Lesson plan merupakan sesuatu yang dipersiapkan secara sistematis dalam suatu pembelajaran yang akan dimanifestasikan bersama-sama peserta didik. Lesson plan juga merupakan proses penyusunan materi pelajaran, penggunaan media pengajaran, penggunaan pendekatan dan metode pengajaran, dan penilaian dalam suatu alokasi waktu yang akan dilaksanakan pada masa tertentu untuk mencapai tujuan yang telah ditentukan (Nadzir, 2013). Sedangkan menurut Wina Sanjaya dalam (Utomo, 2012), lesson plan adalah proses pengambilan keputusan hasil berpikir secara rasional tentang sasaran dan tujuan pembelajaran, yakni perubahan perilaku serta rangkaian kegiatan yang harus dilaksanakan sebagai upaya pencapaian tujuan tersebut dengan memanfaatkan segala potensi dan sumber yang ada.

Penyusunan lesson plan yang dilakukan secara sistematis atau dilandasi dengan pendekatan sistem dan memberi dua keuntungan besar, yaitu: 1). Sebagai suatu alat untuk menganalisis, mengidentifikasi, dan memecahkan masalah sesuai dengan yang diinginkan. 2). Memiliki daya ramal dan kontrol yang baik, karena didukung dengan langkah-langkah: a). Perumusan kebutuhan secara spesifik dan nyata; b). Penggunaan logika, proses setapak demi setapak untuk menuju perubahan yang diharapkan; c). Perhatian dan penentuan salah satu diantara macam- macam pendekatan yang lebih sesuai dengan situasi dan kondisi; d). Penetapan mekanisme feedback yang memberi informasi tentang kemajuan, hambatanhambatan, serta perubahan-perubahan yang diperlukan; dan e). Penggunaan istilah dan langkah yang jelas, mudah dikomunikasikan dan dipahami orang lain.

Permasalahan umum yang sering terjadi pada pembelajaran matematika adalah tidak maksimalnya proses pembelajaran yang dilakukan oleh guru. Hal ini mengakibatkan rendahnya prestasi belajar siswa dalam mata pelajaran matematika. Berdasarkan hasil wawancara dengan guru di SMPN 9 Kota Madiun dan SMPN 4 Kota Madiun, tidak 
maksimalnya proses pembelajaran yang dilakukan guru diakibatkan oleh anggapan bahwa potensi yang dimiliki oleh siswa hanyalah potensi akademik. Dengan anggapan tersebut, maka proses pembelajaran diarahkan kepada penyampaian materi pokok secara monoton dan tidak sesuai dengan potensi awal yang dimiliki oleh siswa. Padahal siswa memiliki potensi awal heterogen dan tidak hanya potensi akademik, dan jika proses pembelajaran yang dilakukan sesuai dengan potensi masing-masing siswa akademik maupun non akademik, maka potensi akademik siswa akan cenderung meningkat.

Potensi siswa merupakan kemampuan yang telah dimiliki oleh siswa, dengan kata lain dapat disebut pula sebagai kecerdasan. Lingkungan yang baik dapat diupayakan untuk mengembangkan kecerdasan siswa sehingga bermuara pada peningkatan potensi akademik. Hal ini sejalan dengan pendapat (Chatib, 2011) bahwa faktor lingkungan dapat dioptimalkan untuk meningkatkan potensi siswa. Faktor lingkungan yang dimaksud dapat berupa proses pembelajaran di sekolah formal. Potensi yang telah dimiliki oleh siswa dapat dipandang dari berbagai segi, potensi atau kecerdasan dari banyak segi inilah yang biasa disebut sebagai Multiple Intelligence. Dengan demikian, proses pembelajaran yang optimal adalah proses pembelajaran yang dapat melibatkan semua potensi yang telah dimiliki oleh siswa dan bermuara pada peningkatan potensi akademik.

Istilah multiple intellegence pertama kali dikemukan oleh Howard Gardner. Gardner berusaha memperluas lingkup potensi manusia melampaui batas-batas skor IQ. Gardner juga menyatakan bahwa kecerdasan berkaitan dengan kapasitas/kemampuan untuk (1) memecahkan masalah-masalah dan (2) menciptakan produk-produk dan karya- karya dalam sebuah konteks yang kaya dengan keadaan yang naturalistik.(Fakhriyah, Roysa, \& Sumaji, 2014).

Menurut Gardner dalam (Fakhriyah et al., 2014) kecerdasan meliputi delapan kemampuan intelektual. Teori tersebut didasarkan pada pemikiran bahwa kemampuan intelektual yang diukur melalui tes IQ sangatlah terbatas karena tes IQ hanya menekan pada kemampuan logika matematika dan bahasa. Akan tetapi, setiap orang mempunyai cara yang unik untuk menyelesaikan persoalan yang dihadapinya. Kecerdasan bukan hanya dilihat dari nilai yang diperoleh seseorang. Kecerdasan merupakan kemampuan yang dimiliki oleh seseorang untuk melihat suatu masalah, lalu menyelesaikan masalah tersebut atau membuat sesuatu yang dapat berguna bagi orang lain. Psikolog Gardner menyediakan sarana untuk memetakan berbagai kemampuan siswa dengan mengelompokkan kemampuan- kemampuan mereka dalam delapan kecerdasan yaitu: kecerdasan linguistik, kecerdasan logis-matematis, kecerdasan visual-spasial, kecerdasan kinestetik- jasmani, kecerdasan musikal, kecerdasan interpersonal, kecerdasan intrapersonal dan kecerdasan naturalis.

Komponen maupun kemampuan untuk masing-masing kecerdasan diuraikan sebagai berikut, (a) linguistik, komponen inti dari kecerdasan ini adalah kepekaan terhadap bunyi, struktur, makna, fungsi kata, dan bahasa. Kemampuan yang dimiliki oleh tipe kecerdasan ini adalah kemampuan membaca, menulis, berdiskusi, berargumentasi, dan berdebat, (b) matematis-logis, komponen inti dari kecerdasan ini adalah kepekaan memahami pola-pola logis atau numerik dan kemampuan mengolah alur pemikiran yang panjang. Kemampuan 
yang dimiliki oleh tipe kecerdasan ini adalah kemampuan berhitung, bernalar dan berpikir logis, memecahkan masalah, (c) visual-spasial, komponen inti dari kecerdasan ini adalah kepekaan merasakan dan membayangkan dunia gambar dan ruang secara akurat. Kemampuan yang dimiliki oleh tipe kecerdasan ini adalah kemampuan menggambar, memotret, membuat patung, mendesain, (d) musik, komponen inti dari kecerdasan ini adalah kepekaan menciptakan dan mengapresiasi irama, pola titi nada, dan warna nada, serta apresiasi bentukbentuk ekspresi emosi musikal. Kemampuan yang dimiliki oleh tipe kecerdasan ini adalah kemampuan menciptakan lagu, membentuk irama, mendengar nada dari sumber bunyi atau alat-alat music, (e) kinestetis, komponen inti kecerdasan ini adalah kepekaan mengontrol gerak tubuh dan kamahiran mengelola objek, respons, dan reflek. Kemampuan yang dimiliki adalah kemampuan gerak motorik dan keseimbangan, (f) interpersonal, komponen inti kecerdasan ini adalah kepekaan mencerna dan merespons secara tepat suasana hati, temperamen, motivasi, dan keinginan orang lain. Sedangkan kemampuan yang dimiliki adalah kemampuan bergaul dengan orang lain, memimpin, kepekaan sosial yang tinggi, negosiasi, bekerja sama, punya empati yang tinggi, (g) intrapersonal, komponen inti kecerdasan ini adalah kepekaan memahami perasaan sendiri dan kemampuan membedakan emosi, pengetahuan tentang kekuatan dan kelemahan diri. Kemampuan yang menjadi ciri khas kecerdasan intrapersonal adalah kemampuan mengenali diri sendiri secara mendalam, kemampuan intuitif dan motivasi diri, penyendiri, sensitif terhadap nilai diri dan tujuan hidup, (h) naturalis, komponen inti kecerdasan ini adalah kepekaan membedakan spesies, mengenali eksistensi spesies lain, dan memetakan hubungan antar beberapa spesies. Kemampuan yang dimiliki adalah kemampuan meneliti gejala alam, mengklasifikasi, identifikasi (Ali, 2014).

Semua manusia memiliki semua kecerdasan tersebut dalam dirinya. Namun, terdapat kecenderungan hanya salah satu kecerdasan yang mendominasi. Menurut (Chatib, 2011) kondisi lingkungan yang kondusif dan selaras dengan kecenderungan kecerdasan yang dimiliki oleh seseorang akan membuat orang tersebut menemukan kondisi akhir yang baik. Dengan demikian, lingkungan yang sesuai dengan salah satu kecenderungan kecerdasan dapat membuat si empunya berhasil dalam memecahkan masalah maupun membuat produk baru yang bernilai budaya. Oleh sebab itu, jika kecerdasan ini dihubungkan dengan dunia pendidikan, khususnya pembelajaran, lingkungan atau kondisi pembelajaran yang melibatkan semua kecerdasan tersebut dalam prosesnya, akan membuat siswa yang memiliki kecenderungan kecerdasan tertentu mendapatkan hasil belajar yang baik.

Beberapa penelitian terdahulu telah menunjukan hasil yang positif dengan menggunakan multiple intelligence seperti (Huda \& Arief, 2013) yang menyatakan bahwa penerapan pembelajaran multiple intelligences menggunakan model pembelajaran Kooperatif Tipe Jigsaw di kelas eksperimen mendapat respons yang baik dari siswa dan (Laamena, 2013) yang menyatakan pembelajaran matematika yang menggunakan Multiple Intelligence memudahkan siswa dalam memahami konsep matematika.

Berdasarkan semua uraian di atas, tujuan dari penelitian ini, yaitu untuk mengetahui secara tertulis, apakah prestasi belajar matematika siswa dapat meningkat melalui penerapan 
lesson plan berbasis Multiple Intelligence. Keterbaruan penulis dalam penelitian ini yaitu penulis menggunakan lesson plan yang berbasis mutiple intelligence dalam penelitiannya.

\section{METODE PENELITIAN}

Jenis penelitian ini adalah penelitian studi literatur. Dengan demikian, untuk mencapai tujuan penelitian yang telah dijelaskan sebelumnya, terdapat beberapa hal yang dilakukan oleh peneliti, yaitu (a) mengumpulkan literatur kemudian melakukan review terhadap beberapa istilah penting dalam penelitian. Beberapa literatur diperoleh dari berbagai sumber referensi. Istilah penting yang didefinisikan dalam penelitian ini adalah prestasi belajar matematika dan lesson plan berbasis Multiple Intelligence, (b) mengumpulkan literatur hasil penelitian relevan. Hasil penelitian yang relevan diperoleh dan digunakan untuk memperkaya proses analisis, sehingga hasil analisis mampu memunculkan kesimpulan yang obyektif, (c) melakukan analisis secara mendalam berdasarkan semua literatur yang telah diperoleh dengan menyusun pembahasan. Pembahasan dilakukan untuk menyimpulkan tentang peningkatan prestasi belajar matematika siswa melalui penerapan lesson plan berbasis Multiple Intelligence, (d) menyusun kesimpulan berdasarkan hasil analisis. Kesimpulan yang diperoleh adalah pernyataan yang sesuai dengan tujuan penelitian, (e) mengajukan saran berdasarkan temuan-temuan yang diperoleh. Temuan-temuan yang diperoleh berdasarkan proses analisis dapat dijadikan sebagai masukkan, yang nantinya bermanfaat bagi peneliti maupun pembaca.

\section{HASIL PENELITIAN DAN PEMBAHASAN}

\section{Hasil Penelitian}

Berdasarkan tahapan penelitian pada metodologi penelitian, dapat diuraikan beberapa hasil penelitian, yaitu (a) pengumpulan literatur telah dilaksanakan, semua literatur tertulis pada daftar pustaka. Berdasarkan pengumpulan literatur tersebut telah dilakukan review terhadap beberapa istilah penting yang berkaitan langsung dengan penelitian. Hasil review terhadap beberapa istilah penting dapat dilihat pada bagian pendahuluan, (b) telah dilakukan pengumpulan literatur tentang hasil penelitian yang relevan. Beberapa penelitian yang relevan dengan penelitian ini adalah (1) penelitian yang dilakukan oleh (Melissa, 2016), yang berjudul, "Pengembangan Perangkat Pembelajaran Topik Lingkaran Berbasis Kecerdasan Majemuk Gardner Berorientasi pada Prestasi dan Kemandirian Belajar". Salah satu kriteria pengembangan yang digunakan oleh penelitian tersebut adalah efektif. Kriteria efektivitas perangkat pembelajaran yang dikembangkan diperoleh dari prestasi belajar matematika siswa. Dari hasil pelaksaan tes prestasi belajar matematika, diperoleh sebanyak $88,86 \%$ siswa tuntas secara klasikal. Hal ini menunjukkan bahwa perangkat pembelajaran berbasis Kecerdasan Majemuk Gardner yang dihasilkan efektif jika ditinjau dari prestasi belajar siswa.

Penelitian lain yang juga relevan dengan penelitian ini adalah (2) penelitian yang dilakukan oleh (Laamena, 2013)), yang berjudul, "Pembelajaran Matematika dengan Multiple Intelligence untuk Menumbuhkan Nilai Karakter". Salah satu kesimpulan hasil penelitian tersebut adalah pembelajaran matematika dengan Multiple Intelligence mampu mempermudah siswa untuk memahami materi pelajaran. Namun, masih terlalu dini untuk menyimpulkan hal tersebut, karena penelitian hanya sebatas sebagai kajian, tanpa ada rujukan 
penelitian yang relevan, sehingga belum ada dukungan data yang menunjukkan kesimpulan tersebut berlaku dan dapat digeneralisasi. Selain itu, (3) penelitian yang dilakukan oleh (Huda \& Arief, 2013), yang berjudul, "Pengaruh Multiple Intelligence menggunakan Model Pembelajaran Kooperatis Tipe Jigsaw terhadap Hasil Belajar Siswa Pada Pokok Bahasan Listrik Dinamis Kelas X di SMAN 1 Porong". Salah satu kesimpulan hasil penelitian tersebut adalah pembelajaran fisika yang menggunakan Multiple Intelligence dengan Model Pembelajaran Kooperatif Tipe Jigsaw memberikan pengaruh positif terhadap hasil belajar siswa Kelas X SMAN 1 Porong pada sub pokok bahasan listrik dinamis. Pengaruh positif ini diperoleh berdasarkan terdapatnya hubungan secara signifikan antara Nilai Multiple Intelligence menggunakan Pembelajaran Kooperatif tipe Jigsaw dengan kemampuan kognitif, afektif, dan psikomotorik siswa. Hubungan secara signifikan diperoleh berdasarkan analisis regresi, sehingga diperoleh koefisien korelasi (r) yang masuk dalam kategori sangat tinggi.

Tahapan selanjutnya adalah (c) melakukan analisis secara mendalam berdasarkan semua literatur yang telah diperoleh dengan menyusun pembahasan. Proses analisis dilakukan di bagian pembahasan yang dituliskan pada bagian selanjutnya. Demikian juga dengan tahapan penelitian (d) dan (e), akan dituliskan pada bagian selanjutnya.

\section{Pembahasan}

Permasalahan umum yang sering terjadi pada pembelajaran matematika adalah tidak maksimalnya proses pembelajaran yang dilakukan oleh guru. Hal ini mengakibatkan rendahnya prestasi belajar siswa, khususnya prestasi belajar siswa dalam mata pelajaran matematika. Berdasarkan hasil wawancara dengan guru di dua sekolah tersebut, tidak maksimalnya proses pembelajaran yang dilakukan guru diakibatkan oleh anggapan bahwa potensi yang dimiliki oleh siswa hanyalah potensi akademik. Dengan anggapan tersebut, maka proses pembelajaran diarahkan kepada penyampaian materi pokok secara monoton dan tidak sesuai dengan potensi awal yang dimiliki oleh siswa.

Potensi yang telah dimiliki oleh siswa untuk melakukan suatu tindakan sering disebut dengan kecerdasan. Kecerdasan dapat dipandang dari banyak segi. Teori kecerdasan ini disebut sebagai Multiple Intelligence. Penyampaian materi pokok membutuhkan rencana pelaksanaan pembelajaran. Rencana pembelajaran yang melibatkan beberapa ranah kecerdasan sesuai teori Multiple Intelligence disebut sebagai lesson plan berbasis Multiple Intelligence. Selain melibatkan beberapa ranah kecerdasan, lesson plan berbasis Multiple Intelligence juga menggunakan teori apersepsi dan memperhatikan modalitas belajar siswa. Dengan penerapan teori apersepsi, mampu membangkitkan energi positif siswa dan mengkondisikan siswa sehingga perhatian mereka akan terpusat pada proses pembelajaran. Selain itu, penerapan teori apersepsi juga dapat mengarahkan siswa untuk masuk ke zona alfa, zona terbaik untuk melakukan apersepsi karena siswa merasa nyaman sebelum mengikuti proses pembelajaran. Dengan demikian, proses pembelajaran menjadi lebih menyenangkan dan tidak monoton.

Lesson plan berbasis Multiple Intelligence juga memperhatikan modalitas belajar, dengan memperhatikan semua modalitas belajar yang dimiliki siswa, ada jaminan bahwa informasi dapat diterima baik oleh siswa. Jika informasi diterima baik oleh siswa, ada 
kemungkinan informasi yang diberikan pada saat proses pembelajaran mampu terekam dalam memori jangka panjang, sehingga hasil proses pembelajaran dapat maksimal. Hal ini yang membuat penerapan lesson plan berbasis Multiple Intelligence dalam proses pembelajaran matematika memungkinkan adanya peningkatan potensi akademik siswa. Potensi akademik merupakan hasil belajar ranah kognitif, yang pada penelitian ini disebut dengan istilah prestasi belajar matematika.

Kecederungan peningkatan prestasi belajar siswa melalui penerapan lesson plan berbasis Multiple Intelligence, didukung oleh hasil dari penelitian (Melissa, 2016). Menurut hasil penelitian tersebut, siswa tuntas dalam belajar secara klasikal melalui penggunaan perangkat pembelajaran berbasis kecerdasan majemuk Gardner yang menyebabkan pengembangan perangkat pembelajaran menjadi efektif. Demikian juga hasil penelitian yang diperoleh (Laamena, 2013) bahwa pembelajaran matematika yang menggunakan Multiple Intelligence memudahkan siswa dalam memahami konsep matematika, tentu hal ini berhubungan dengan peningkatan prestasi belajar matematika siswa. Hasil penelitian yang dilakukan oleh (Huda \& Arief, 2013) juga menyimpulkan bahwa pada pembelajaran fisika yang menggunakan Multiple Intelligence pada pokok bahasan listrik dinamis memberikan pengaruh positif terhadap hasil belajar siswa.

\section{SIMPULAN DAN SARAN}

Berdasarkan hasil penelitian dan pembahasan di atas, dapat diperoleh suatu kesimpulan secara tertulis bahwa penerapan lesson plan berbasis Multiple Intelligence memiliki kecenderungan untuk dapat meningkatkan prestasi belajar matematika siswa. Sehingga dapat diajukan beberapa saran, yaitu (a) karena lesson plan berbasis Multiple Intelligence secara tertulis memiliki kecenderungan untuk dapat meningkatkan prestasi belajar matematika, maka perlu dilakukan suatu penelitian lanjutan guna menunjukkan apakah memang kesimpulan yang dihasilkan tersebut didukung oleh data di lapangan, (b) jika hasil analisis data di lapangan memperoleh kesimpulan yang sama, maka lesson plan berbasis Multiple Intelligence dapat dijadikan sebagai alternatif untuk memaksimalkan proses pembelajaran matematika di kelas, (c) beberapa manfaat yang mungkin didapatkan berdasarkan penerapan lesson plan berbasis Multiple Intelligence pada proses pembelajaran matematika adalah materi yang disampaikan tidak monoton dan siswa merasa nyaman dalam mengikuti pembelajaran proses pembelajaran, siswa akan lebih mudah memahami materi pembelajaran, karena ada pelibatan Multiple Intelligence yang dimiliki siswa, (d) lesson plan berbasis Multiple Intelligence yang baik adalah lesson plan yang menerapkan apersepsi sesuai dengan frekuensi otak manusia dan berdasarkan pada modalitas belajar siswa, (e) sistematika dalamrangka penyusunan lesson plan berbasis Multiple Intelligence dapat mengikuti sistematika yang disarankan oleh Chatib yang disebut dengan sistematika lesson plan yang kreatif. 


\section{DAFTAR PUSTAKA}

Ali, N. (2014). Supervisi Pembelajaran Kepala Madrasah Dalam Pelaksanaan Kurikulum 2013 Dengan Multiple Intellegences Dan Emotional Intelligence Pada Madrasah Ibtidaiyah. Madrasah, 7(1), 163-182.

Chatib, M. (2011). Sekolahnya Manusia Sekolah Berbasis Multiple Intelligence di Indonesia. Bandung: Kaifa.

Fakhriyah, F., Roysa, M., \& Sumaji. (2014). Penerapan Pembelajaran Tematik Berwawasan Multiple Intellegence Dalam Upaya Membentuk Karakter Siswa Di SD IT Al Islam Kudus. Refleksi Edukatika, 4(1).

Huda, M., \& Arief, A. (2013). Pengaruh Multiple Intelligences Menggunakan Model Pembelajaran Kooperatif Tipe Jigsaw Terhadap Hasil Belajar Siswa Pada Pokok Bahasan Listrik Dinamis Kelas X Di SMAN 1 Porong. Jurnal Inovasi Pendidikan Fisika, 2(3), 34-37.

Kusnandar. (2013). Penilaian Autentik (Penilaian Hasil Belajar Siswa Berdasarkan Kurikulum 2013). Jakarta: PT Raja Grafindo Persada.

Laamena, C. M. (2013). Pembelajaran Matematika dengan Multiple Intelligence untuk Menumbuhkan Nilai Karakter. FMIPA Universitas Pattimura, 226-232.

Maja, I. (2013). Pengaruh Motivasi, Metode Pembelajaran Dan Disiplin Belajar Terhadap Prestasi Belajar Matematika Teknik Di Politeknik Negeri Sriwijaya (Studi Penelitian Pada Mahasiswa Jurusan Teknik Kimia). Jurnal Orasi Bisnis, 9(3), 1-10.

Melissa, M. M. (2016). Perangkat Pembelajaran Topik Lingkaran Berbasis Kecerdasan Majemuk Gardner Berorientasi pada Prestasi dan Kemandirian Belajar. Widya Warta, (2), 296-309.

Nadzir, M. (2013). Perencanaan Pembelajaran Berbasis Karakter. Jurnal Pendidikan Agama Islam, 2(2), 338-352.

Pamungkas, M., Nugraheni, P., \& Astuti, E. P. (2013). Eksperimentasi Pembelajaran Kooperatif Tipe NHT (Numbered Heads Together) Dan TPS(Think Pair Share) Terhadap Prestasi Belajar Matematika Siswa Pada Materi Fungsi Kelas VIII SMP Negeri 40 Purworejo Tahun Pelajaran 2012/2013. Ekuivalen, 4(1), 53-58.

Ratnasari, M. (2013). Pengaruh Persepsi Siswa Tentang Profesionalisme Guru Dan Penggunaan Media Pembelajaran Terhadap Prestasi Belajar Akuntansi Keuangan Siswa Kelas XI Program Keahlian Akuntansi SMK Negeri 1 Depok Tahun Ajaran 2011/2012. Kajian Pendidikan Akuntansi Indonesia, 2(1), 208-225.

Saputra, I., Sriyono, \& Ngazizah, N. (2013). Penggunaan Strategi Konstruktivisme Dalam Pembelajaran Fisika Untuk Meningkatkan Partisipasi Siswa Kelas VIII E SMP. Radiasi, $3(2), 125-128$.

Supardi, Sunarno, W., \& Haryono. (2014). Pengaruh Pendekatan Kontruktivisme Dengan Metode Inkuiri Terbimbing Dan Eksperimen Terhadap Prestasi Belajar Fisika Ditinjau Dari Sikap Ilmiah Siswa. Prosiding Seminar Nasional Pendidikan Sains, 1(1), 1-9. 
Utomo, S. W. (2012). Pengaruh Prestasi Belajar Perencanaan Pengajaran Dan Micro Teaching Terhadap Praktik Pengalaman Lapangan Mahasiswa Pendidikan Akuntansi IKIP PGRI Madiun. Jurnal Akuntansi Dan Pendidikan, 1(2), 56-65. 